\title{
Technical note: Lithium isotopes in dolostone as a palaeo-environmental proxy - an experimental approach
}

\author{
Holly L. Taylor ${ }^{1}$, Isaac J. Kell Duivestein ${ }^{2}$, Juraj Farkas ${ }^{3,4}$, Martin Dietzel ${ }^{2}$, and Anthony Dosseto ${ }^{1}$ \\ ${ }^{1}$ Wollongong Isotope Geochronology Laboratory, School of Earth, Atmospheric and Life Sciences, University of \\ Wollongong, Wollongong, NSW, Australia \\ ${ }^{2}$ Institute of Applied Geosciences, Graz University of Technology, Graz, Austria \\ ${ }^{3}$ Department of Earth Sciences, University of Adelaide, Adelaide, SA, Australia \\ ${ }^{4}$ Department of Environmental Geosciences, Czech University of Life Sciences, Prague, Czech Republic
}

Correspondence: Holly L. Taylor (hlt434@uowmail.edu.au)

Received: 22 August 2018 - Discussion started: 4 September 2018

Revised: 11 March 2019 - Accepted: 11 March 2019 - Published: 4 April 2019

\begin{abstract}
Lithium $(\mathrm{Li})$ isotopes in marine carbonates have considerable potential as a proxy to constrain past changes in silicate weathering fluxes and improve our understanding of Earth's climate. To date the majority of Li isotope studies on marine carbonates have focussed on calcium carbonates. The determination of the $\mathrm{Li}$ isotope fractionation between dolomite and a dolomitizing fluid would allow us to extend investigations to deep times (i.e. Precambrian) when dolostones were the most abundant marine carbonate archives. Dolostones often contain a significant proportion of detrital silicate material, which dominates the Li budget; thus, pretreatment needs to be designed so that only the isotope composition of the carbonate-associated $\mathrm{Li}$ is measured. This study aims to serve two main goals: (1) to determine the $\mathrm{Li}$ isotope fractionation between $\mathrm{Ca}-\mathrm{Mg}$ carbonates and solution, and (2) to develop a method for leaching the carbonateassociated $\mathrm{Li}$ out of dolostone while not affecting the Li contained within the detrital portion of the rock. We synthesized $\mathrm{Ca}-\mathrm{Mg}$ carbonates at high temperatures $\left(150\right.$ to $\left.220^{\circ} \mathrm{C}\right)$ and measured the $\mathrm{Li}$ isotope composition $\left(\delta^{7} \mathrm{Li}\right)$ of the precipitated solids and their respective reactive solutions. The relationship of the Li isotope fractionation factor with tempera-
\end{abstract} ture was obtained:

$$
\begin{gathered}
10^{3} \ln \alpha_{\text {prec-sol }}=-\left((2.56 \pm 0.27) 10^{6}\right) \\
/ T^{2}+(5.8 \pm 1.3)
\end{gathered}
$$

Competitive nucleation and growth between dolomite and magnesite were observed during the experiments; however, there was no notable effect of their relative proportion on the apparent $\mathrm{Li}$ isotope fractionation. We found that $\mathrm{Li}$ isotope fractionation between the precipitated solid and solution is higher for $\mathrm{Ca}-\mathrm{Mg}$ carbonates than for $\mathrm{Ca}$ carbonates. If the temperature of a precipitating solution is known or can be estimated independently, the above equation could be used in conjunction with the $\mathrm{Li}$ isotope composition of dolostones to derive the composition of the solution and hence make inferences about the past $\mathrm{Li}$ cycle. In addition, we also conducted leaching experiments on a Neoproterozoic dolostone and a Holocene coral. Results show that leaching with $0.05 \mathrm{M}$ hydrochloric acid $(\mathrm{HCl})$ or $0.5 \%$ acetic acid $(\mathrm{HAc})$ at room temperature for $60 \mathrm{~min}$ releases $\mathrm{Li}$ from the carbonate fraction without a significant contribution of Li from the siliciclastic detrital component. These experimental and analytical developments provide a basis for the use of $\mathrm{Li}$ isotopes in dolostones as a palaeo-environmental proxy, which will contribute to further advance our understanding of the evolution of Earth's surface environments.

\section{Introduction}

Lithium isotopes in marine carbonates have emerged as a powerful proxy to help understand the evolution of the ocean chemistry, past silicate weathering fluxes and their links to global climate. Application to calcium carbonates (e.g. foraminifera, limestone) has shed some light on hotly de- 
bated topics such as, the evolution of Earth's climate during the Cenozoic (Misra and Froelich, 2012; Li et al., 2014; Wanner et al., 2014; Vigier and Goddéris, 2015; Hathorne and James, 2006), oceanic anoxic events (Pogge von Strandmann et al., 2013; Lechler et al., 2015) and Palaeozoic glaciation (Pogge von Strandmann et al., 2017). Although postdepositional alteration can play an important role in the formation of dolomite (Geske et al., 2012; Burns et al., 2000), the application of $\mathrm{Li}$ isotopes to marine dolostone could help to extend our understanding of the geochemical evolution of ancient dolomitizing solutions, particularly in early Earth geological history (i.e. Precambrian).

While data of $\mathrm{Li}$ isotopic fractionation during calcite precipitation have been relatively well constrained (Marriott et al., 2004a, b; Dellinger et al., 2018), there are currently no data available pertaining to $\mathrm{Li}$ isotope fractionation during dolomite formation. Therefore, in this study, precipitation experiments were carried out at various temperatures (150-220 ${ }^{\circ} \mathrm{C}$ ), during which the $\mathrm{Li}$ isotopic composition of the precipitated solids and their respective reactive solutions were measured in order to determine the fractionation factor between the fluid and solid phases. The experiments were conducted at elevated temperatures due to the impossibility of synthesizing well-ordered dolomite at ambient temperatures on a laboratory timescale (Land, 1998; Arvidson and Mackenzie, 1999; Gregg et al., 2015).

One major difficulty with interpreting $\mathrm{Li}$ isotopes in dolostone is that they often contain a significant proportion of siliciclastic material (e.g. detrital micas and/or authigenic clay minerals). The abundance of $\mathrm{Li}$ in silicate minerals is higher than in carbonates (typically more than 2 orders of magnitude); thus, sample pretreatment must be undertaken to extract Li from only the carbonate fraction (Pogge von Strandmann et al., 2013; Bastian et al., 2018). Therefore, in this study we have tested various pretreatment methods in order to refine a procedure that faithfully yields the isotopic composition of the carbonate-associated Li fraction in dolostones exclusively.

\section{Methods}

\subsection{Ca-Mg carbonate synthesis}

Synthesis of $\mathrm{Ca}-\mathrm{Mg}$ carbonates was conducted in Teflonlined, stainless steel autoclaves at temperatures of 150, 180 and $220^{\circ} \mathrm{C} \pm 5^{\circ} \mathrm{C}$ ) through the reaction of $\sim 300 \mathrm{mg}$ of powdered inorganic aragonite (speleothem aragonite; in-house mineral collection at Graz University of Technology) with an artificial brine solution containing $200 \mathrm{mM} \mathrm{Mg}, 0.245 \mathrm{mM}$ $\mathrm{Li}$ and $50 \mathrm{mM} \mathrm{NaHCO}$. The reactive fluid was prepared by dissolving analytical grade $\mathrm{MgCl}_{2.6} \mathrm{H}_{2} \mathrm{O}$ (Roth; $\geq 99 \%$, p.a., ACS), $\mathrm{LiCl}$ (Merck; $\geq 99 \%$, ACS, Reag. Ph Eur) and $\mathrm{NaHCO}_{3}$ (Roth; $\geq 99.5 \%$, p.a., ACS, ISO) in ultrapure water (Millipore Integral 3: $18.2 \mathrm{M} \Omega \mathrm{cm}^{-1}$ ). The stock solution was subsequently filtered through a $0.45 \mu \mathrm{m}$ cellulose acetate membrane filter (Sartorius). The reagent inorganic aragonite was milled to a grain size $<20 \mu \mathrm{m}$ using a vibratory mill (McCrone Micronizing Mill) for $10 \mathrm{~min}$ and collected by dry sieving prior to use in the experiments. Autoclaves were sealed immediately after mixing the inorganic aragonite with the appropriate volume of stock solution and placed in preheated ovens. Samples were taken from the autoclaves at each operating temperature after a given reaction time (Table 1), including repeat samples. Upon removal from heat, the reactors were quenched and the samples were filtered through a $0.2 \mu \mathrm{m}$ cellulose acetate membrane (Sartorius) using a vacuum filtration unit. Samples were then thoroughly rinsed with ultrapure water (Millipore Integral 3: $18.2 \mathrm{M} \Omega \mathrm{cm}^{-1}$ ) to remove any soluble salts from the matrix and dried in an oven at $40^{\circ} \mathrm{C}$ overnight to prepare them for subsequent solid phase analysis. An aliquot of the reactive fluid was acidified to a $\sim 3 \% \mathrm{HNO}_{3}$ matrix for elemental and $\mathrm{Li}$ isotope analyses using Merck ${ }^{\circledR}$ Suprapur ${ }^{\mathrm{TM}} \mathrm{HNO}_{3}$.

\subsection{Leaching experiments}

A Neoproterozoic dolostone from the Nuccaleena Formation (Flinders Ranges, South Australia, $\sim 635 \mathrm{Ma}$ ) and a Holocene Porites coral were used to evaluate the effect of different leaching protocols on the measured $\mathrm{Li}$ isotope composition. Samples were ground to a powder using a TEMA chromium-ring grinding mill. An aliquot of powdered dolostone was used for mineralogy quantification performed using X-ray diffraction. Another aliquot of $1 \mathrm{~g}$ was placed in a clean polypropylene centrifuge tube and $20 \mathrm{~mL}$ of solution was added. Leaching was tested with hydrochloric acid $(\mathrm{HCl})$ of varying concentrations $(0.05,0.1,0.15,0.2,0.3$, $0.5,0.8,1$ and 6) and acetic acid (HAc) at concentrations of $0.5 \%$ and $2 \%$. HAc and $\mathrm{HCl}$ solutions were prepared from trace grade glacial acetic acid (Merck ${ }^{\circledR}$ Suprapur $^{\mathrm{TM}}$ ) and ultra-trace grade $30 \% \mathrm{HCl}\left(\right.$ Merck $^{\circledR}$ Suprapur $^{\mathrm{TM}}$ ). In each case, the powder and solution reacted at room temperature for $1 \mathrm{~h}$, while continuous mixing was achieved with an orbital shaker. The supernatant fluid was separated by centrifugation at $4000 \mathrm{rpm}$ for $15 \mathrm{~min}$. After separation, the supernatant fluid was extracted using acid-washed disposable pipettes. An aliquot containing $\sim 60 \mathrm{ng}$ of $\mathrm{Li}$ was subsequently sampled for cation exchange chromatography.

\subsection{Mineralogy quantification}

Quantitative phase contents of the synthesized solids were determined by powder X-ray diffraction (XRD) of finely ground aliquots performed on a PANalytical X'Pert PRO diffractometer outfitted with a Co-target tube (operated at $40 \mathrm{kV}$ and $40 \mathrm{~mA}$ ), a high-speed X'Celerator Scientific detector, $0.5^{\circ}$ antiscatter and divergence slits, spinner stage, primary and secondary Soller and automatic sample changer. Samples were finely ground by hand using a mortar and pestle prior to analysis and were loaded in a random orientation 
Table 1. Reaction temperatures and mineral content from the precipitation experiments.

\begin{tabular}{lrrrrr}
\hline Sample ID & $\begin{array}{r}\text { Reaction time } \\
\text { (days) }\end{array}$ & $\begin{array}{r}T \\
\left({ }^{\circ} \mathrm{C}\right)\end{array}$ & Magnesite & Dolomite & $\begin{array}{r}\text { Dolomite/ } \\
\text { magnesite }\end{array}$ \\
\hline LiDol - 150-4.1 & 150 & 150 & 18.0 & 82.0 & 4.56 \\
LiDol - 150-4.2 & 150 & 150 & 34.0 & 66.0 & 1.94 \\
LiDol - 150-4.3 & 150 & 150 & 30.0 & 61.0 & 2.03 \\
LiDol - 180-4.1 & 150 & 180 & 31.0 & 69.0 & 2.23 \\
LiDol - 180-4.2 & 150 & 180 & 64.0 & 36.0 & 0.56 \\
LiDol - 220-3 & 100 & 220 & 83.0 & 17.0 & 0.20 \\
\hline
\end{tabular}

Mineral content in wt $\%$. Note a maximum reaction time of 100 days was only possible at $220^{\circ} \mathrm{C}$, as no reacting solution was left after this time.

using the top loading technique. The samples were analysed over the $4-85^{\circ} 2 \theta$ range with a step size of $0.008^{\circ} 2 \theta$ and a count time of $40 \mathrm{sstep}^{-1}$. Mineral quantification was obtained by Rietveld refinement of the XRD patterns using the PANalytical X'Pert HighScore Plus software and its implemented pdf-2 database.

\subsection{Elemental concentrations}

Lithium concentrations of solutions were analysed in acidified $\left(0.3 \mathrm{M} \mathrm{HNO}_{3}\right)$ aliquots by inductively coupled plasma optical emission spectroscopy (ICP-OES) using a PerkinElmer Optima 8300. A range of in-house and NIST 1640a standards were measured at the beginning and end of a sample series, with an estimated analytical error $(2 \sigma$, three replicates) of $\pm 3 \%$ relative to the standard. For synthesized solids, an aliquot of each precipitate was dissolved in $0.9 \mathrm{M}$ $\mathrm{HNO}_{3}$ at $70^{\circ} \mathrm{C}$ for $12 \mathrm{~h}$ in an ultrasonic bath to ensure complete digestion. Subsequently, Li concentrations were analysed by ICP-OES following the same method as for the aqueous solutions.

\subsection{Lithium isotopes}

Sample preparation for $\mathrm{Li}$ isotope measurement was undertaken in a class 100 clean room at the Wollongong Isotope Geochronology Laboratory, University of Wollongong. For mineral precipitates, the samples were ground using a mortar and pestle before aliquots of $<0.05 \mathrm{~g}$ were weighed. The sample aliquots were dissolved in dilute $\mathrm{HNO}_{3}$ (Ultrapur ${ }^{\mathrm{TM}}$ ), and $0.2 \mathrm{~mL}$ of concentrated $\mathrm{H}_{2} \mathrm{O}_{2}\left(31 \%\right.$ Ultrapur $\left.^{\mathrm{TM}}\right)$ was added to ensure the breakdown of organics.

The samples were then placed on a hotplate overnight at $50^{\circ} \mathrm{C}$ to reflux and ensure complete digestion of the solids. After complete digestion of the solids, Li concentrations were measured by quadrupole ICP-MS. An aliquot of the digested samples containing $\sim 60 \mathrm{ng}$ of $\mathrm{Li}$ was then dried down and taken up into $1.5 \mathrm{~mL}$ of Ultrapur ${ }^{\mathrm{TM}} 1 \mathrm{M} \mathrm{HCl}$. Samples were then treated with a two-step cation exchange chromatography procedure, following the methods of Balter and Vigier (2014) to separate $\mathrm{Li}$ from the sample matrix. For $\mathrm{Li}$ isotope measurements it is crucial that $100 \%$ of $\mathrm{Li}$ is recovered from the cation exchange columns as $\delta^{7} \mathrm{Li}$ compositions have been shown to vary by up to $\sim 200 \%$ during chromatography due to incomplete recovery (Pistiner and Henderson, 2003). It is also crucial to remove elements such as $\mathrm{Na}$ and $\mathrm{Ca}$ as large amounts of $\mathrm{Ca}$ can coat the cones of the mass spectrometer, whereas $\mathrm{Na}$ can reduce $\mathrm{Li}$ ionization in the plasma and cause further Li isotopic fractionation during analysis (James and Palmer, 2000). For chromatography, $30 \mathrm{~mL}$ Savillex micro columns $(6.4 \mathrm{~mm}$ internal diameter, $9.6 \mathrm{~cm}$ external diameter, $25 \mathrm{~cm}$ capillary length) were used together with Bio-Rad AG50W-X8 resin as the cation exchange medium (volume of $3.06 \mathrm{~cm}^{3}$ ). The columns were calibrated with seawater prior to treating the samples to verify that the procedure yielded $100 \%$ of the $\mathrm{Li}$ (Table A1 in the Appendix). The columns were cleaned with $30 \mathrm{~mL}$ of $6 \mathrm{M} \mathrm{HCl}$, rinsed with $2 \mathrm{~mL}$ of $\mathrm{MilliQ}^{\mathrm{TM}}$ water and conditioned using $8 \mathrm{~mL}$ of titrated, $1 \mathrm{M}$ Ultrapur $^{\mathrm{TM}}$ $\mathrm{HCl}$ before sample loading. To ensure the complete removal of interfering elements from the $\mathrm{Li}$, samples were passed through the columns twice; after the first elution, the samples were dried down, taken up in $1 \mathrm{M} \mathrm{HCl}$ and reloaded into the columns. The Li elutions were dried down and subsequently re-dissolved in Ultrapur ${ }^{\mathrm{TM}} 0.3 \mathrm{M} \mathrm{HNO}_{3}$ ready for isotopic analysis. Lithium isotope ratios were measured by multi-collector inductively coupled plasma mass spectrometry (MC ICP-MS) on a ThermoFisher Neptune Plus at the Wollongong Isotope Geochronology Laboratory, University of Wollongong. A $30 \mathrm{ppb}$ solution of IRMM-16 Li isotopic standard was used at the start of each measurement session to tune the instrument. An intensity of $\sim 1 \mathrm{~V}$ was routinely obtained for ${ }^{7} \mathrm{Li}$, whereas the background ${ }^{7} \mathrm{Li}$ intensity was between 5 and $30 \mathrm{mV}$. During analysis, standard bracketing, using IRMM-16 as the primary standard, was applied to correct the measured ${ }^{7} \mathrm{Li} /{ }^{6} \mathrm{Li}$ values for mass bias (Flesch et al., 1973). Instrumental blanks were measured before each sample so that the background signal could be accounted for. The ${ }^{7} \mathrm{Li} /{ }^{6} \mathrm{Li}$ ratios were converted to $\delta^{7} \mathrm{Li}$ values using $\mathrm{L}-\mathrm{SVEC}$ 
as reference to Carignan et al. (2007) (Eq. 2).

$\delta^{7} \mathrm{Li}=\left(\left({ }^{7} \mathrm{Li} /{ }^{6} \mathrm{Li}\right)_{\text {sample }} /\left({ }^{7} \mathrm{Li} /{ }^{6} \mathrm{Li}\right)_{\mathrm{L}-\mathrm{SVEC}}\right)-1 \times 1000$

The accuracy of the analysis was assessed using synthetic solutions, Li6-N and Li7-N (Carignan et al., 2007), as secondary standards every six samples. The accuracy of the chromatography and analysis was assessed using a seawater standard (Table A1). External uncertainty on $\delta^{7} \mathrm{Li}$ compositions (at the $2 \sigma$ level) was evaluated by measurement of precipitated solids and solutions from repeat experiments at $150{ }^{\circ} \mathrm{C}(n=3)$ and $180{ }^{\circ} \mathrm{C}(n=2)$, and amounted to $0.86 \%$ o for precipitated solids and $1.2 \%$ for solutions.

\section{Results}

\subsection{Precipitation experiments}

Synthesized minerals are comprised of dolomite and magnesite (Table 1); their relative amount shows a relationship with temperature, with higher reaction temperatures yielding more magnesite and less dolomite compared with lower temperatures (Fig. 1). The Li concentration of reactive solutions ranges from 1666 to $3695 \mu \mathrm{g} \mathrm{L}^{-1}$ (Table A2) and shows no correlation with reaction temperature. On the contrary, the $\mathrm{Li}$ concentration of precipitated solids is consistent with (Marriott et al., 2004a, b) as it decreases with increasing temperature (from 25.9 to $8.20 \mathrm{ppm}$; Table A2).

The $\delta^{7} \mathrm{Li}$ of the initial reactive solution is $7.85 \%$ (Table 2 ). After reaction the $\delta^{7} \mathrm{Li}$ values of the solution $\left(\delta^{7} \mathrm{Li}_{\text {sol }}\right)$ vary between 7.87 and $9.48 \%$, whereas the $\delta^{7} \mathrm{Li}$ values in the precipitated solid $\left(\delta^{7} \mathrm{Li}_{\text {prec }}\right)$ range from $-0.63 \%$ to $3.08 \%$ (Table 2). The precipitated solids are $4.79 \%$ to $8.6 \%$ lighter than the solution, and this difference (termed $10^{3} \ln \alpha_{\text {prec-sol }}$ ) increases with decreasing temperature (Table 2).

The $\mathrm{Li}$ isotope fractionation factors of the precipitated solid and the solution, calculated as $10^{3} \ln \alpha_{\text {prec-sol }}=$ $10^{3} \ln \left(1000+\delta^{7} \mathrm{Li}_{\text {prec }} / 1000+\delta^{7} \mathrm{Li}_{\text {sol }}\right)$, display values within error of each other, despite the wide range of concentrations of dolomite or magnesite precipitated (Fig. 2). Similarly, there is no relationship between the $\mathrm{Li}$ distribution coefficient between precipitated solid and solution $\left(D_{[\mathrm{Li}] \text { prec-sol }}=\right.$ $[\mathrm{Li}]_{\text {prec }} /[\mathrm{Li}]_{\text {sol }}$, where $[\mathrm{Li}]_{\text {prec }}$ and $[\mathrm{Li}]_{\text {sol }}$ are the $\mathrm{Li}$ concentrations in the precipitated solid and the solution, respectively), and mineral abundances (Fig. 3). Conversely, there is a positive relationship between $10^{3} \ln \alpha_{\text {prec-sol }}$ and the reaction temperature (Fig. 4).

\subsection{Leaching experiments}

For the dolostone, $\delta^{7} \mathrm{Li}$ values of the leaching solution decrease from 9.5 to $4.0 \%$, with increasing $\mathrm{HCl}$ concentration (Table 3; Fig. 5a). The molar $\mathrm{Al} / \mathrm{Mg}$ ratio in the leaching solutions increases at $\mathrm{HCl}$ concentrations $>0.8 \mathrm{M}$ from $\sim 0.0009$ to 0.01 (Fig. 5b). The leaching solutions show
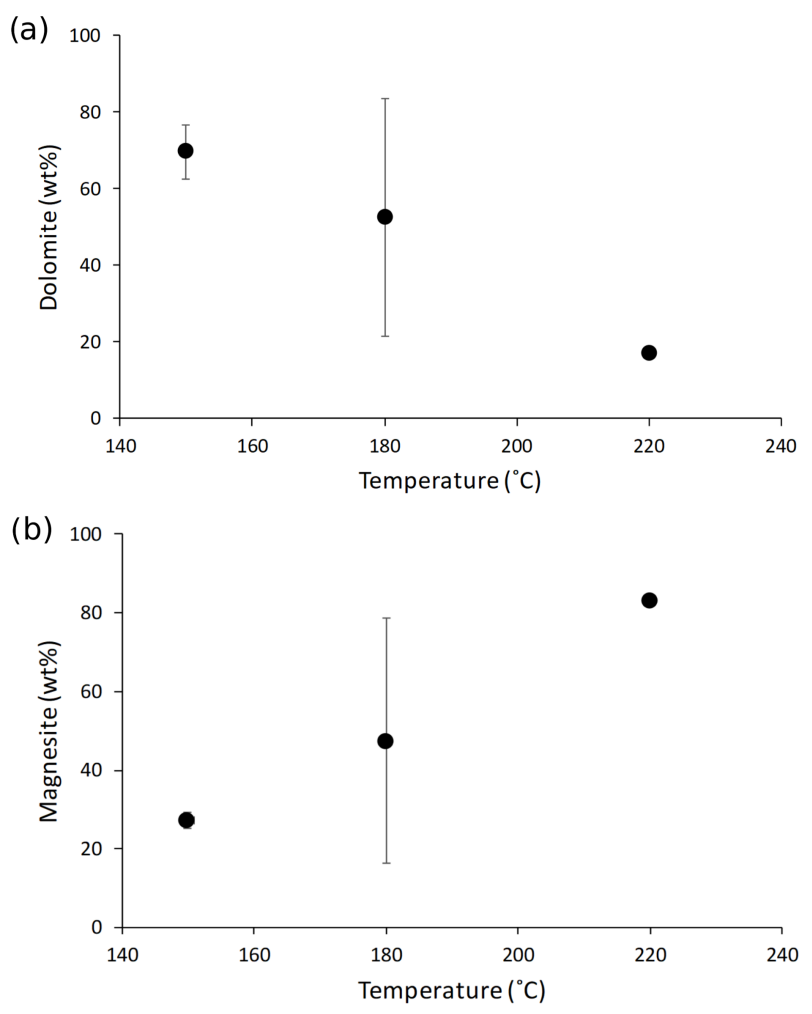

Figure 1. (a) Dolomite and (b) magnesite concentrations in the precipitated solid (in wt \%) as a function of reaction temperature (in ${ }^{\circ} \mathrm{C}$ ). The data displayed are average values for each reaction temperature. The error is not shown for mineral concentrations at $220^{\circ} \mathrm{C}$ because no repeat analysis was performed. The error on the magnesite content at $150{ }^{\circ} \mathrm{C}$ is within the symbol size.

an increase in the molar $\mathrm{Li} / \mathrm{Ca}$ ratio from $6.3 \times 10^{-6}$ to $25 \times 10^{-6}$ with decreasing $\delta^{7} \mathrm{Li}$ (Fig. 6a). Furthermore, the molar $\mathrm{Li} / \mathrm{Mg}$ ratio increases from 5 to $12 \times 10^{-5}$ with increasing $\delta^{7} \mathrm{Li}$ (Fig. 6b). Very few carbonate minerals other than dolomite (1.1 wt \% calcite and $2.1 \mathrm{wt} \%$ ankerite) are present in the dolostone sample, and the silicate minerals represents $\sim 26 \mathrm{wt} \%$ of the sample (14 wt \% quartz, $6.2 \mathrm{wt} \%$ muscovite and $5.1 \mathrm{wt} \%$ albite) (Table A3). Leaching with HAc yields $\delta^{7} \mathrm{Li}$ compositions in the solution similar to values observed with very dilute $\mathrm{HCl}$ (Fig. 7). The $\delta^{7} \mathrm{Li}$ of the $2 \%$ HAc leaching solution is lower than that of the $0.5 \%$ HAc leaching solution.

For the Holocene coral, the sample is dominated by aragonite (Table A4) and the leaching solution shows a similar trend to that from the dolostone leaching experiment, with $\delta^{7} \mathrm{Li}$ values decreasing from 20.1 to 16.9 with increasing $\mathrm{HCl}$ concentration (Table 3; Fig. 8). Total dissolution of the coral yields a $\delta^{7} \mathrm{Li}$ value in the solution of $20.6 \%$, which is within error of the values determined for $\mathrm{HCl}$ leaching experiments with acid concentrations $<0.5 \mathrm{M}$ (Table 3 ). 
Table 2. Li isotope composition in solutions and precipitated solids for the precipitation experiments.

\begin{tabular}{lrrrrr}
\hline Sample ID & $\begin{array}{r}\text { Temperature } \\
\left({ }^{\circ} \mathrm{C}\right)\end{array}$ & $\begin{array}{r}\delta^{7} \mathrm{Li} \text { solution } \\
(\% \circ)\end{array}$ & $\begin{array}{r}\delta^{7} \mathrm{Li} \text { solid } \\
(\%)\end{array}$ & $10^{3} \ln \left(\alpha_{\text {prec-sol }}\right)$ & $D_{\text {[Li]prec-sol }}$ \\
\hline LiCl reactive solution & - & 7.85 & - & - & - \\
LiDol - 150-4.1 & 150 & 7.87 & 0.03 & -7.81 & 7.01 \\
LiDol - 150-4.2 & 150 & 8.34 & -0.63 & -8.93 & 6.00 \\
LiDol - 150-4.3 & 150 & 8.79 & -0.10 & -8.86 & 7.19 \\
LiDol - 180-4.1 & 180 & 9.48 & 2.88 & -6.56 & 4.66 \\
LiDol - 180-4.2 & 180 & 7.88 & 1.71 & -6.14 & 4.85 \\
LiDol - 220-3 & 220 & 7.87 & 3.08 & -4.77 & 4.92 \\
\hline
\end{tabular}

External uncertainty (at the $2 \sigma$ level) is $0.86 \%$ and $1.2 \%$ on the $\delta^{7} \mathrm{Li}$ values of precipitated solids and solutions, respectively.
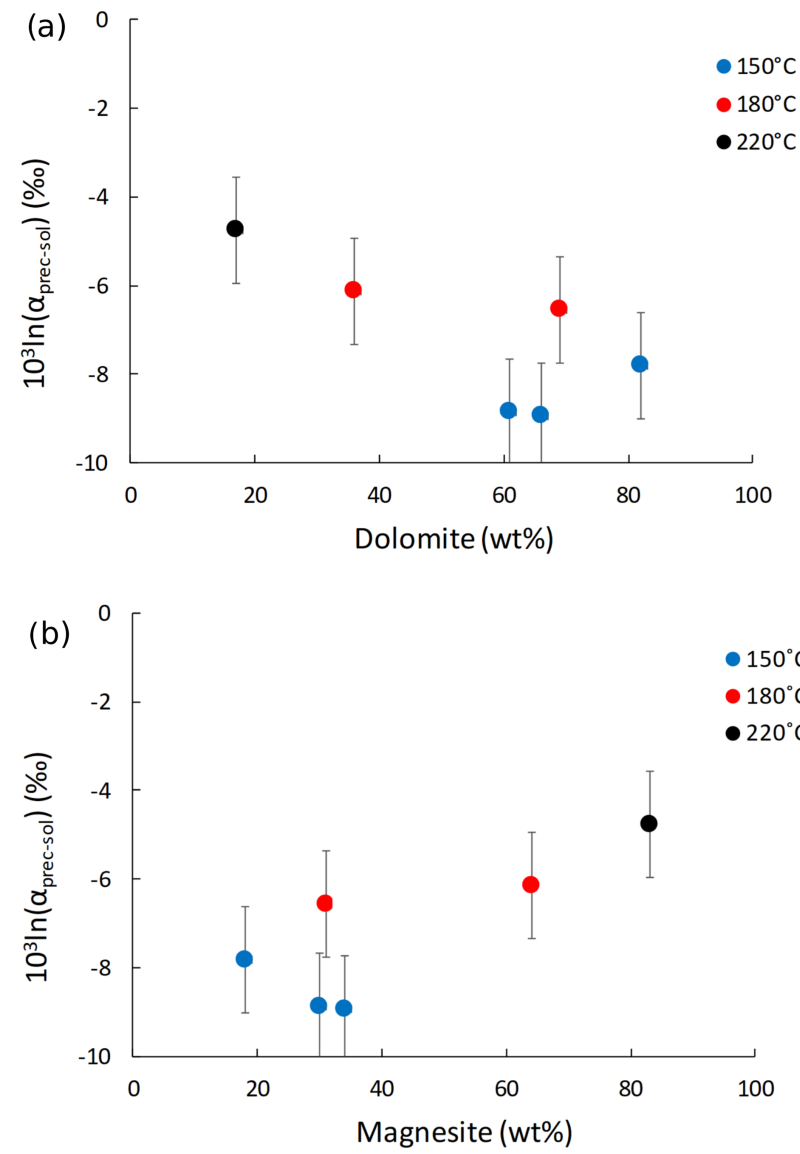

Figure 2. Lithium isotope fractionation factor between the precipitated solid and the solution $\left(10^{3} \ln \alpha_{\text {prec-sol }}\right)$ as a function of (a) dolomite and (b) magnesite content (in wt \%).

\section{Discussion}

\subsection{Lithium isotope fractionation during inorganic precipitation of $\mathrm{Ca}-\mathrm{Mg}$ carbonate}

The precipitated solids of the synthesis experiments consist of $\mathrm{Ca}-\mathrm{Mg}$ carbonates with variable amounts of dolomite $\left(\mathrm{CaMg}\left(\mathrm{CO}_{3}\right)_{2}\right)$ and magnesite $\left(\mathrm{MgCO}_{3}\right)$ (Table 1). The $\delta^{7} \mathrm{Li}$
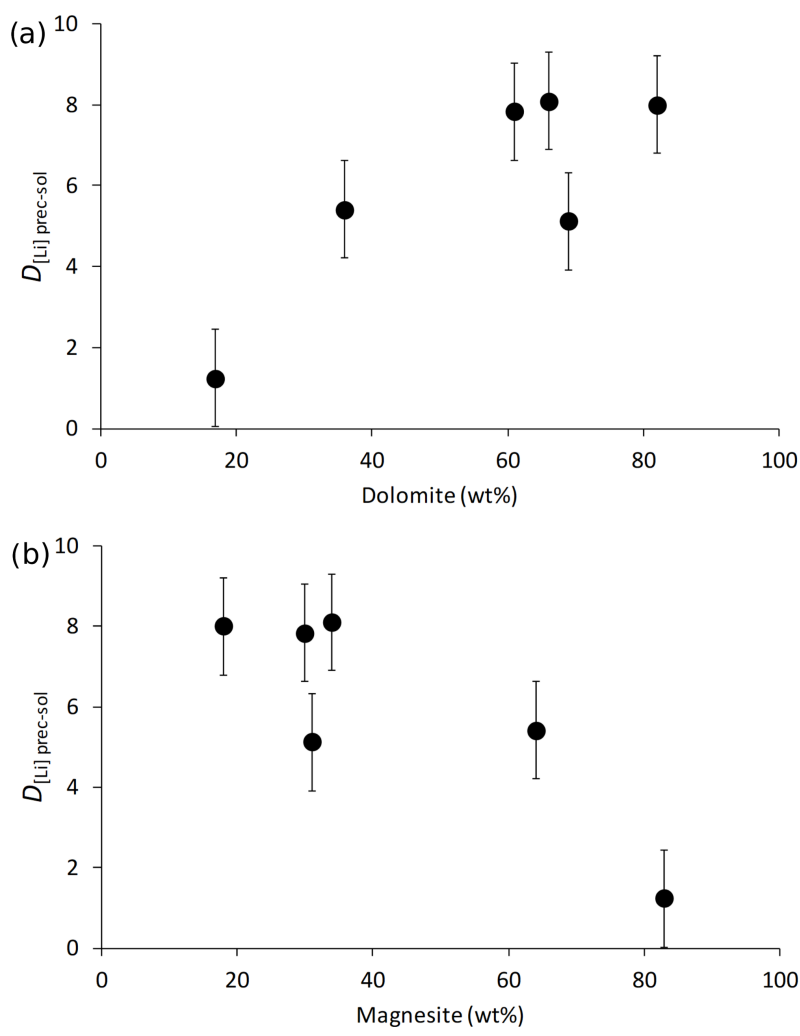

Figure 3. The distribution coefficient of Li between solid and solution $\left(D_{[\mathrm{Li}] \text { prec-sol }}\right)$ as a function of (a) dolomite content and (b) magnesite content (in wt \%).

composition of the precipitated solids is systematically isotopically lighter than that of the reactive solution (Table 2). These results are consistent with previous experimental work on $\mathrm{Li}$ isotope fractionation during calcite precipitation (Marriott et al., 2004a, b), which showed that the Li isotope composition of calcite is isotopically lighter than that of the corresponding fluid. Teng et al. (2008) suggested that the incorporation of ${ }^{6} \mathrm{Li}$ over ${ }^{7} \mathrm{Li}$ in minerals compared to the growth solution reflects a change from four- to six-fold coordination of $\mathrm{Li}$ during mineral growth. In calcite from foraminifera 


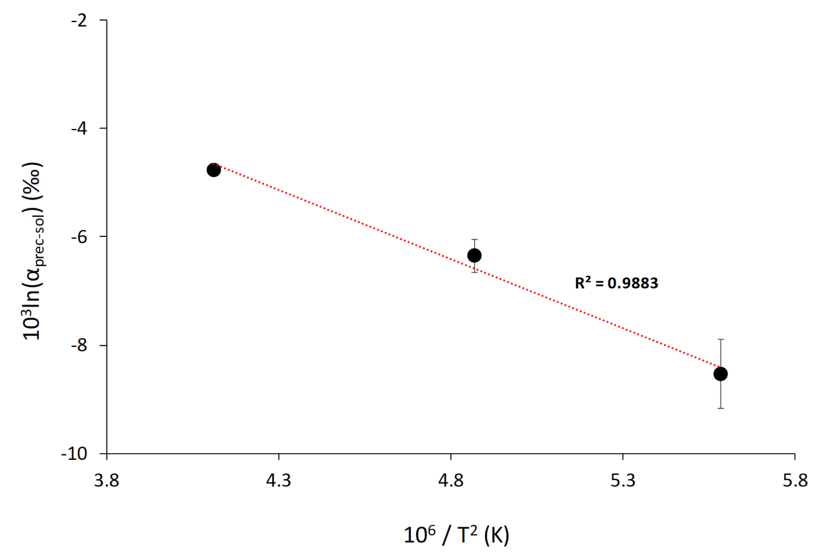

Figure 4. Lithium isotope fractionation factor as a function of the reaction temperature, $T$ (in $\mathrm{K}$ ). Average values for each temperature are shown. The dotted line shows the linear regression through these values according to Eq. (3). Error is not shown for the isotope fractionation factor at $220^{\circ} \mathrm{C}$ because no repeat analysis was performed.

and aragonite from corals, $\delta^{7} \mathrm{Li}$ values are about $3 \%$ and $11 \%$ o lower, respectively, compared with their growth solutions (Marriott et al., 2004a). Here, the precipitated minerals are $4.8 \%$ o to $8.6 \pm 0.6 \%$ o $(1 \sigma ; n=3)$ lighter than the solution over all temperatures $\left(150,180\right.$ and $\left.220^{\circ} \mathrm{C}\right)$. This difference increases with decreasing temperature, as would be expected for stable isotope fractionation at equilibrium. As our experiments were conducted at high temperatures (150, 180 and $220^{\circ} \mathrm{C}$ ), the system can reasonably be considered to be approaching isotope equilibrium conditions as fractionation scales with the inverse of reaction temperature (see Fig. 3). Marriott et al. (2004a) suggested that Li isotope fractionation probably occurs at equilibrium even at lower temperatures for several reasons: (i) kinetic fractionation would probably be much greater (up to $\sim 80 \%$ o) than that observed (both in calcite and in $\mathrm{Ca}-\mathrm{Mg}$ carbonate), and would therefore require boundary layer processes or the presence of a back-reaction, for which there is no evidence; (ii) observed isotopic fractionation between calcite and growth solution, as well as between $\mathrm{Ca}-\mathrm{Mg}$ carbonate and growth solution, are consistent with ab initio calculations for equilibrium fractionation (Kazuyo et al., 2001); and (iii) lithium isotope fractionation between calcite and growth solution is relatively constant across a wide range of concentrations of $\mathrm{Li}$ incorporated in calcite (this was not tested here).

Although $\mathrm{Li}$ isotope fractionation and the magnesite/dolomite ratio of the precipitated solid both co-vary with temperature, there is no relationship between the $\delta^{7} \mathrm{Li}$ composition of the precipitated solids or that of their respective reactive solutions and the magnesite/dolomite ratio of the precipitated solid (not shown). This suggests that the nature of the $\mathrm{Ca}-\mathrm{Mg}$ carbonate precipitated does not have a significant influence on $\mathrm{Li}$ isotope fractionation. This
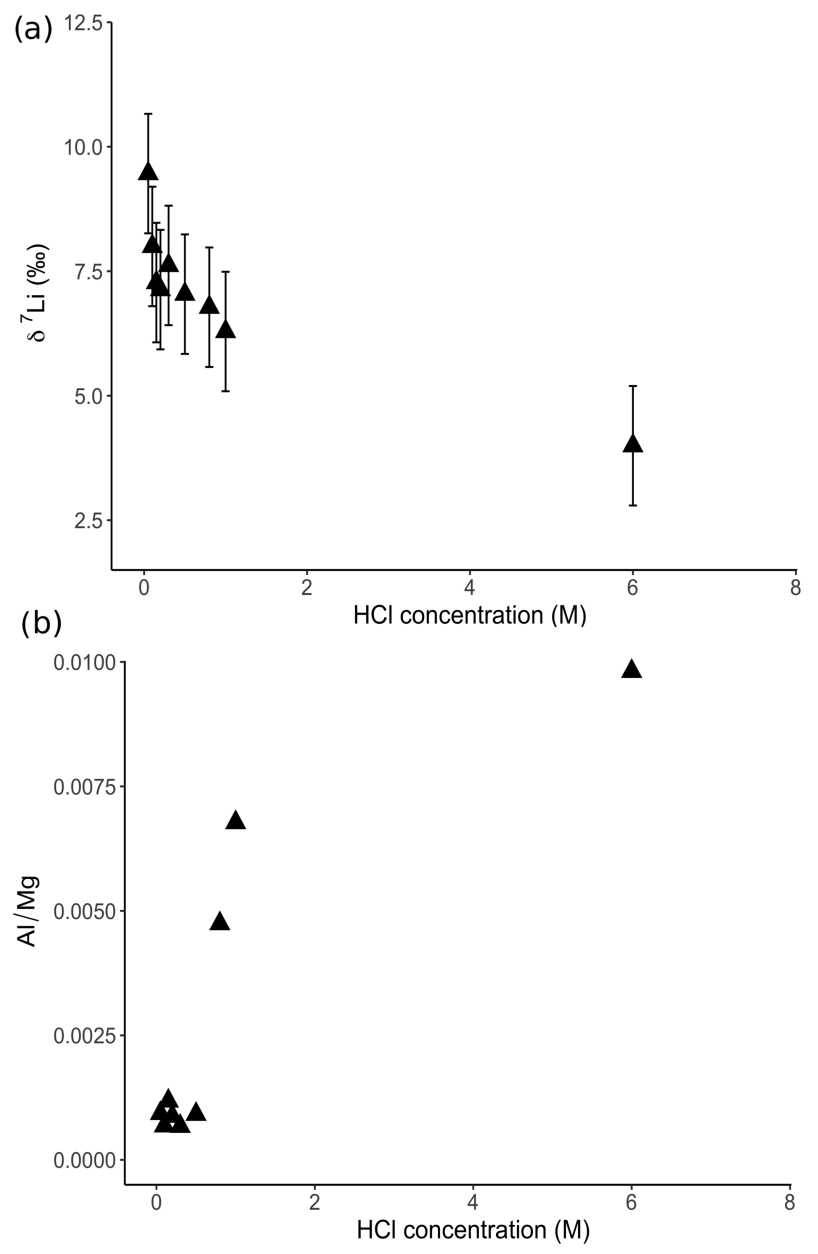

Figure 5. (a) Lithium isotope compositions and (b) $\mathrm{Al} / \mathrm{Mg}$ ratios of solutions from dolostone leaching, as a function of their $\mathrm{HCl}$ concentration. Decreasing $\delta^{7} \mathrm{Li}$ values with increasing $\mathrm{HCl}$ concentration suggest a release of isotopically light Li from clay minerals, which is supported by the increase in the $\mathrm{Al} / \mathrm{Mg}$ ratios. Error bars are within the symbol size, if not shown.

hypothesis is supported by the absence of significant variation in the $\mathrm{Li}$ isotope fractionation factor $\left(10^{3} \ln \alpha_{\text {prec-sol }}\right.$; Fig. 2) or the Li distribution coefficient between solid and solution $\left(D_{[\mathrm{Li}] p r e c-s o l}\right.$; Fig. 3$)$, despite a wide range of mineral abundances. For instance, most $10^{3} \ln \alpha_{\text {prec-sol }}$ values are within error of each other, whereas the dolomite concentration varies from $17 \mathrm{wt} \%$ to $82 \mathrm{wt} \%$ (Fig. 2a). This differs from what Marriott et al. (2004b) observed for calcium carbonates at ambient temperature, where the isotopic fractionation in aragonite $(\sim 11 \%$ o) was much greater than in calcite $(\sim 3 \%$ ) .

The relationship between $10^{3} \ln \alpha_{\text {prec-sol }}$ and temperature can be used to estimate the temperature dependency for $\mathrm{Li}$ isotope fractionation between $\mathrm{Ca}-\mathrm{Mg}$ carbonate and solution. Using average $10^{3} \ln \alpha_{\text {prec-sol values for each reaction }}$ temperature, we obtain the following temperature-dependent 
Table 3. Lithium isotope compositions and elemental concentrations of solutions from the dolostone and coral leaching experiments with $\mathrm{HCl}$ and $\mathrm{HAc}$.

\begin{tabular}{|c|c|c|c|c|c|c|}
\hline $\begin{array}{l}\mathrm{HCl} \text { concentration } \\
\text { (M) }\end{array}$ & $\begin{array}{r}\delta^{7} \mathrm{Li}_{\mathrm{d}} \\
(\% \circ)\end{array}$ & $\begin{array}{r}\delta^{7} \mathrm{Li}_{\mathrm{c}} \\
(\% \circ)\end{array}$ & $\begin{array}{r}\mathrm{Al} \\
(\mathrm{ppb})\end{array}$ & $\begin{array}{r}\mathrm{Li} \\
(\mathrm{ppb})\end{array}$ & $\begin{array}{r}\mathrm{Mg} \\
(\mathrm{ppm})\end{array}$ & $\begin{array}{r}\mathrm{Ca} \\
(\mathrm{ppm})\end{array}$ \\
\hline 0.05 & 9.46 & 20.1 & 151.0 & 19.8 & 162.0 & 3151.1 \\
\hline 0.10 & 8.00 & 20.2 & 241.5 & 28.6 & 353.3 & 3407.1 \\
\hline 0.15 & 7.27 & 20.2 & 637.4 & 32.4 & 538.9 & 3206.8 \\
\hline 0.20 & 7.13 & 19.5 & 712.3 & 38.4 & 811.8 & 3612.8 \\
\hline 0.30 & 7.62 & 19.3 & 848.9 & 51.3 & 1257.6 & 3984.8 \\
\hline 0.50 & 7.04 & 17.8 & 2024.1 & 81.0 & 2209.0 & 4867.5 \\
\hline 0.80 & 6.78 & 7.04 & 13588.1 & 114.6 & 2864.1 & 5649.2 \\
\hline 1.00 & 6.29 & 16.7 & 21984.3 & 110.4 & 3245.4 & 6714.2 \\
\hline 6.00 & 4.00 & 16.9 & 32541.9 & 161.7 & 3317.0 & 6406.7 \\
\hline Total dissolution & $\mathrm{n} / \mathrm{a}$ & 20.6 & & & & \\
\hline $\begin{array}{l}\text { HAc concentration } \\
(\%)\end{array}$ & $\begin{array}{r}\delta^{7} \mathrm{Li}_{\mathrm{d}} \\
(\% \circ)\end{array}$ & & & & & \\
\hline 0.5 & 10.9 & & & & & \\
\hline 2 & 8.37 & & & & & \\
\hline
\end{tabular}

$\delta^{7} \mathrm{Li}_{\mathrm{d}}(\% o)$ and $\delta^{7} \mathrm{Li}_{\mathrm{c}}(\% o)$ are the $\mathrm{Li}$ isotope composition of solutions from dolostone and coral leaching experiments, respectively. $\mathrm{n} / \mathrm{a}$ denotes not applicable.

relationship:

$$
\begin{gathered}
10^{3} \ln \alpha_{\text {prec-sol }}=-\left((2.56 \pm 0.27) 10^{6}\right) \\
/ T^{2}+(5.8 \pm 1.3),
\end{gathered}
$$

where $T$ is the temperature of precipitation in Kelvin.

Using Eq. (3), the Li isotopic fractionation at $25^{\circ} \mathrm{C}$ is estimated to be $-23.0 \pm 5.7 \%$ ( $1 \sigma)$ (Fig. 4). Although there is a large error on this estimate, our results suggest that $\mathrm{Li}$ isotopic fractionation during dolomite/magnesite precipitation is significantly larger than during calcium carbonate precipitation (Marriott et al., 2004a). This temperaturedependant relationship of $\mathrm{Li}$ isotope fractionation in our high-temperature experiments follows the isotope fractionation approach considering equilibrium fractionation (Hoefs, 2015). Furthermore, we see that at high temperature ${ }^{6} \mathrm{Li}$ is preferentially incorporated into the mineral phase over ${ }^{7} \mathrm{Li}$, which is similar to what has been observed at low temperature for calcium carbonate (Marriott et al., 2004a, b). Finally, despite a wide range of formation conditions between high-temperature synthetic dolomites and low-temperature natural dolomites, Kaczmarek and Sibley (2007) showed that natural and synthetic dolomite form by the same growth mechanisms. This was suggested via the identification of identical growth features in etched natural and synthetic dolomite samples as well as unetched synthetic dolomite. The growth fabrics of high-temperature synthetic dolomite and low-temperature natural dolomite have also been compared by Bullen and Sibley (1984), and these results suggest that high-temperature synthetic dolomites produce fabrics similar to those of naturally grown dolomites. Alto- gether, these observations suggest that the relationship between $\mathrm{Li}$ isotope fractionation and temperature derived from high-temperature experiments may also be valid at low temperatures characteristic of natural environments.

If the temperature of the solution from which dolomite is precipitated is known or can be calculated (e.g. via clumped $\Delta_{47}$ proxy; Winkelstern et al., 2016), the above relationship in combination with the $\delta^{7} \mathrm{Li}$ of dolostone could potentially be used to determine an estimate for the $\mathrm{Li}$ isotopic composition of the precipitating palaeo-solution, e.g. brine or seawater. It is important to note that the applicability to natural systems may be limited to dolomite precipitated inorganically, whereas it has been proposed that bacterial mediation could play a major role in the precipitation of dolomite from natural waters at ambient conditions (Vasconcelos et al., 1995). Bacterial mediation was invoked to solve the "dolomite problem", i.e. the inability to precipitate dolomite at ambient temperatures; the topic of the origin of dolomite formation is still being hotly debated (Liu et al., 2019; Ahm et al., 2019; Gregg et al., 2015). Other models invoke a primary or secondary (diagenetic) origin for dolomite. Primary marine deposition has been invoked for dolomite formation in many studies, even in Precambrian dolostones (Fairchild and Kennedy, 2007; Rose and Maloof, 2010; Kunzmann et al., 2013; Liu et al., 2014). Thus, where it can be shown that dolomite is of primary origin, its $\mathrm{Li}$ isotopic composition could provide valuable information on palaeo-environments. 

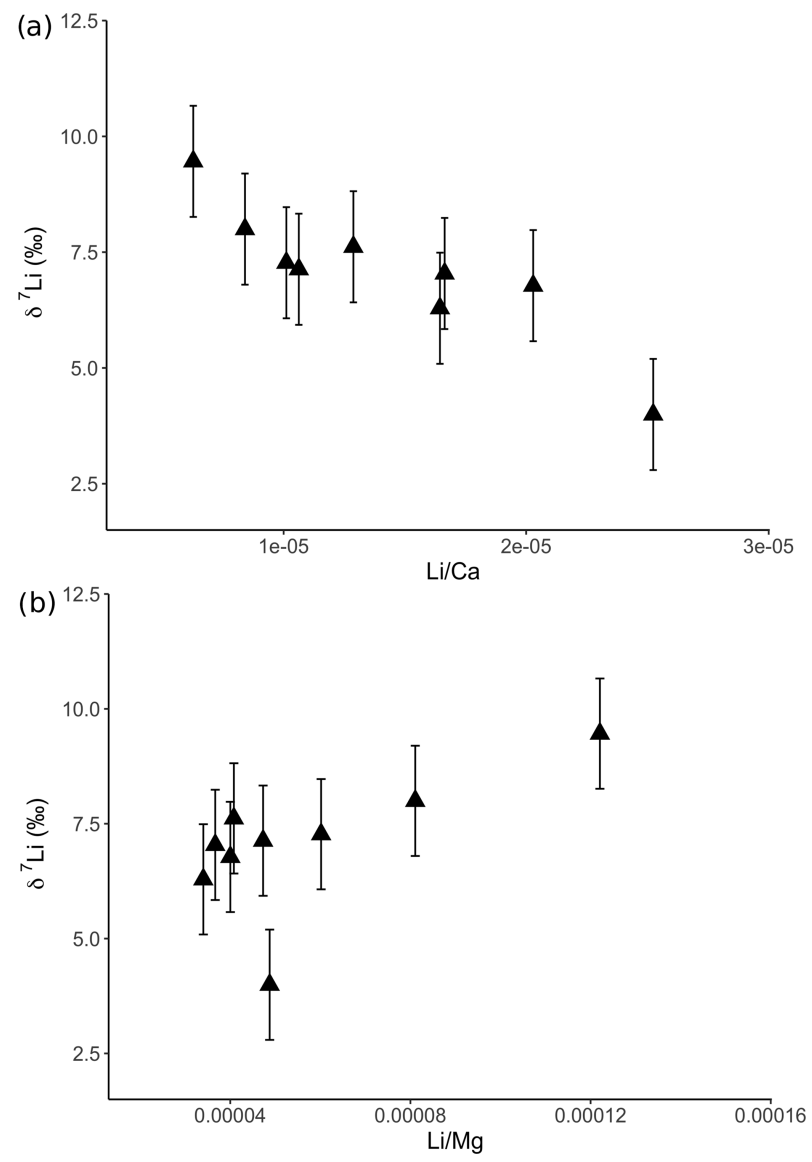

Figure 6. Lithium isotopic compositions of solutions from dolostone leaching, as a function of their (a) $\mathrm{Li} / \mathrm{Ca}$ and (b) $\mathrm{Li} / \mathrm{Mg}$ ratios. Error bars are within the symbol size, if not shown.

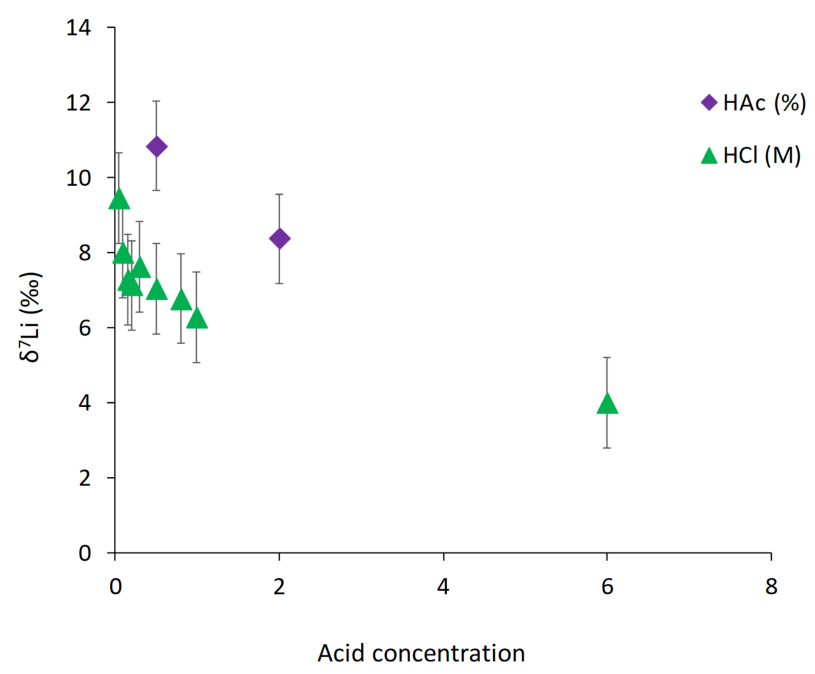

Figure 7. Lithium isotope composition of leaching solutions for experiments with $\mathrm{HCl}$ and $\mathrm{HAc}$.

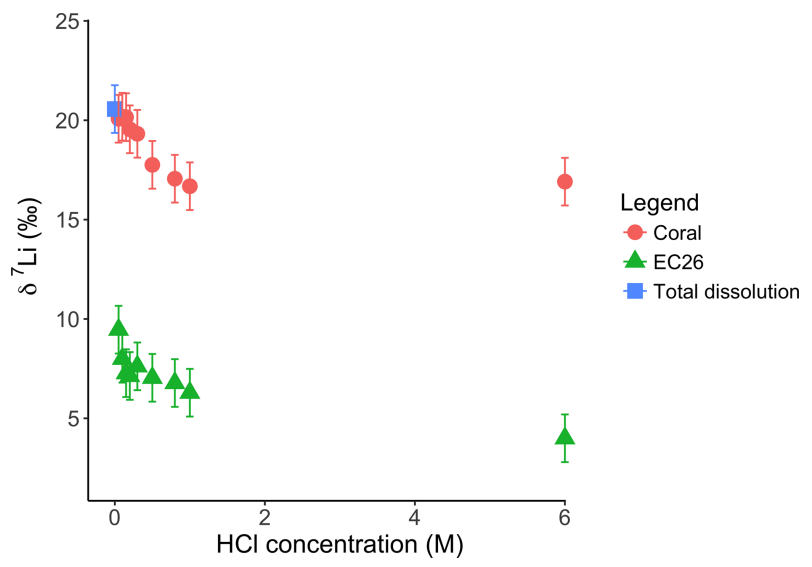

Figure 8. Lithium isotope composition of leaching solutions as a function of their $\mathrm{HCl}$ concentrations. Triangles and circles represent the $\delta^{7} \mathrm{Li}$ composition of the solutions used to leach a Neoproterozoic dolostone and modern coral, respectively. The square shows the composition of the coral total dissolution. Both coral and dolostone solutions show similar trends, suggesting the release of silicate-bound $\mathrm{Li}$ at higher $\mathrm{HCl}$ concentrations. This is surprising as the coral is almost exclusively aragonite, so the release of isotopically light $\mathrm{Li}$ is not expected. This also implies that total dissolution in dilute $\mathrm{HNO}_{3}$ does not release isotopically light $\mathrm{Li}$ into solution, although no residue was observed during dissolution in dilute $\mathrm{HNO}_{3}$.

\subsection{Extraction of carbonate-bound $\mathrm{Li}$ in dolostones}

Leaching of dolostone with solutions of variable $\mathrm{HCl}$ concentrations yields $\delta^{7} \mathrm{Li}$ compositions of the leaching solution that decrease with increasing $\mathrm{HCl}$ concentrations, suggesting an increasing contribution of isotopically light $\mathrm{Li}$ from detrital silicates, such as clay minerals (Fig. 5a). This hypothesis is supported by a negative relationship between $\delta^{7} \mathrm{Li}$ values and $\mathrm{Li} / \mathrm{Ca}$ ratios of the leaching solutions (Fig. 6), which is similar to results from leaching experiments on the Plenus Marl limestone (Pogge von Strandmann et al., 2013). The $\mathrm{Li} / \mathrm{Ca}$ ratio is used instead of $\mathrm{Li} / \mathrm{Mg}$ because $\mathrm{Mg}$ is also present in silicate minerals. Indeed, $\delta^{7} \mathrm{Li}$ and $\mathrm{Li} / \mathrm{Mg}$ ratios show a positive relationship (Fig. 8b), surprisingly suggesting that dolomite and the detrital component are characterized by high and low $\mathrm{Li} / \mathrm{Mg}$ ratios, respectively.

The increasing contribution of silicate minerals with the increasing $\mathrm{HCl}$ concentration of the leaching solution is further illustrated by increasing $\mathrm{Al} / \mathrm{Mg}$ ratios in the leaching solution (Fig. 5b). The contribution from silicates becomes significant for $\mathrm{HCl}$ concentrations $>0.5 \mathrm{M}$. For $\mathrm{HCl}$ concentrations $<0.8 \mathrm{M}$, the relationship between $\mathrm{Al} / \mathrm{Mg}$ and $\mathrm{HCl}$ concentration breaks down (Fig. 5b), indicating that silicates have a negligible role in the composition of the solution. Nevertheless, $\delta^{7} \mathrm{Li}$ values decrease for $\mathrm{HCl}$ concentrations as low as $0.1 \mathrm{M}$. Thus, we propose that treatment of dolostone with a solution of $0.05 \mathrm{M} \mathrm{HCl}$ at room temperature for $60 \mathrm{~min}$ is 
the best compromise between minimizing the contribution of silicates and obtaining enough $\mathrm{Li}$ for isotopic analysis.

Leaching experiments were also conducted on a Porites coral from the Holocene to test the proposed protocol, as the $\delta^{7} \mathrm{Li}$ of modern coral is known (Marriott et al., 2004a; Rollion-Bard et al., 2009). Furthermore, because the aragonitic skeleton of modern corals is generally free of detrital material, we can also test that the chosen leaching protocol yields the same $\mathrm{Li}$ isotopic composition in the resulting solution, as with total dissolution of the coral. Total dissolution of the modern coral yields a $\delta^{7} \mathrm{Li}$ value of $20.6 \%$ (Fig. 8). Leaching solutions with $\mathrm{HCl}$ concentrations $<0.5 \mathrm{M} \mathrm{HCl}$ exhibit $\delta^{7} \mathrm{Li}$ values within error of that obtained from total dissolution. These values are also consistent with $\delta^{7} \mathrm{Li}$ compositions between $18.4 \%$ and $19.6 \%$ measured in Porites, and $21 \%$ in Acropora corals (Marriott et al., 2004a). Biomineralization has no major effect on the incorporation of $\mathrm{Li}$ in coral or foraminifera as $\mathrm{Li}$ has no known biological function. The $\mathrm{Li}$ isotopic difference between coral and seawater is $-11 \%$ (Marriott et al., 2004a). Therefore, $\delta^{7} \mathrm{Li}$ values obtained from the total dissolution and for leaching solutions with a $\mathrm{HCl}$ concentration $<0.5 \mathrm{M}$ would yield a $\delta^{7} \mathrm{Li}$ composition for modern seawater of $31 \%$, consistent with published values (Misra and Froelich, 2012). Consequently, these results, which are similar to that of Dellinger et al. (2018) suggest that leaching with a $0.05 \mathrm{M} \mathrm{HCl}$ solution is appropriate to derive the $\mathrm{Li}$ associated with the carbonate fraction only.

Interestingly both coral and dolostone leaching solutions show a decrease in $\delta^{7} \mathrm{Li}$ values with increasing $\mathrm{HCl}$ concentration. This is surprising as the coral is $97 \%$ aragonite $(2 \%$ magnesite and $1 \%$ calcite) so the release of isotopically light Li from silicates is not expected. These results imply that total dissolution in dilute $\mathrm{HNO}_{3}$ does not release isotopically light $\mathrm{Li}$ into solution, which could be contained in organic colloids, as no residue was observed. The lack of relationship between $\delta^{7} \mathrm{Li}$ values and $\mathrm{Li} / \mathrm{Ca}$ ratios (Fig. A1) suggests that this isotopically light $\mathrm{Li}$ is not bound to silicates (which would have a very different $\mathrm{Li} / \mathrm{Ca}$ from aragonite). In the coral, this pool of Li remains unidentified. However, as shown above, leaching with solutions with $<0.5 \mathrm{M} \mathrm{HCl}$ yield $\mathrm{Li}$ isotope compositions expected for a coral in equilibrium with the modern seawater.

Leaching of dolostone with HAc yields $\delta^{7} \mathrm{Li}$ compositions in the solution similar to that of solutions with a $\mathrm{HCl}$ concentration $\leq 0.1 \mathrm{M}$ (Fig. 7). The $\delta^{7} \mathrm{Li}$ composition of the $2 \%$ HAc solution is lower $(8.37 \%$ ) than that of the $0.5 \% \mathrm{HAc}$ solution, which may suggest a contribution from silicatebound Li. Thus, treatment of dolostone with a solution of $0.5 \%$ HAc at room temperature for $60 \mathrm{~min}$ could be an alternative method to derive carbonate-bound $\mathrm{Li}$.

\section{Summary and conclusions}

Precipitation experiments at high temperatures (150, 180 and $220^{\circ} \mathrm{C}$ ) yielded dolomite and magnesite in variable proportions. However, varying mineralogy does not seem to measurably impact Li isotopic fractionation between the carbonate and the solution. The $\mathrm{Li}$ isotopic composition of the precipitated solid is isotopically lighter than the reactive solution, which is similar to previous experiments on calcium carbonates (Marriott et al., 2004b, a). The isotope fractionation factor is mainly controlled by temperature, which in turn allows us to calculate the $\mathrm{Li}$ isotopic composition of the solution using the $\delta^{7} \mathrm{Li}$ value of the $\mathrm{Ca}-\mathrm{Mg}$ carbonate, if the precipitation temperature can be estimated independently (e.g. oxygen or clumped isotope thermometry). Thus, the temperature-dependent relationship in Eq. (3) could be useful for reconstructing $\delta^{7} \mathrm{Li}$ of palaeo-dolomitizing fluids (i.e. reactive solution) as an approximation based on the $\mathrm{Li}$ isotope composition of dolostones in geological records.

Leaching experiments show that it is possible to selectively dissolve the carbonate-bound $\mathrm{Li}$ in dolostones by using $0.05 \mathrm{M} \mathrm{HCl}$ or $0.5 \% \mathrm{HAc}$ at room temperature for $60 \mathrm{~min}$. Leaching of coral with $0.05 \mathrm{M} \mathrm{HCl}$ shows that this protocol yields a $\mathrm{Li}$ isotope composition for the solution representative of that of the carbonate minerals. Thus, the described protocol allows us to derive the $\mathrm{Li}$ isotope composition of the carbonate fraction of dolostones while leaving the $\mathrm{Li}$ from any co-present silicates intact.

Combined results from leaching and precipitation experiments show that future studies of Li isotopes in dolostones have considerable potential to further constrain the evolution of the $\mathrm{Li}$ isotopic composition of ancient precipitation fluids, including seawater and basinal fluids, and improve our understanding of changes in the Earth's palaeo-environments.

Data availability. Data will be made available upon request. 


\section{Appendix A}

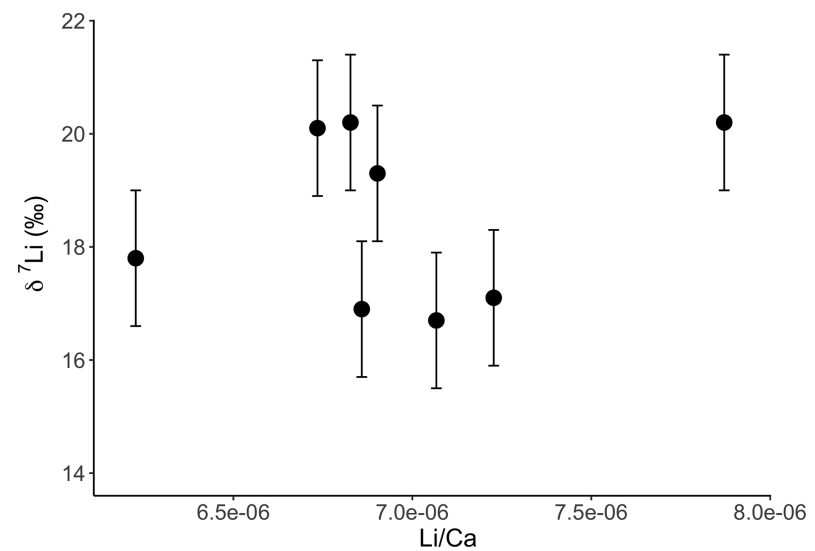

Figure A1. Lithium isotope composition of solutions from coral leaching, as a function of their $\mathrm{Li} / \mathrm{Ca}$ ratio. In contrast to the dolostone, there is no relationship between $\delta^{7} \mathrm{Li}$ and $\mathrm{Li} / \mathrm{Ca}$. This could indicate that the isotopically light $\mathrm{Li}$ is bound to a fraction with a $\mathrm{Li} / \mathrm{Ca}$ similar to that of aragonite. Error bars are within the symbol size, if not shown.

Table A1. Column calibration using seawater samples.

\begin{tabular}{lr}
\hline Column ID & $\delta^{7} \mathrm{Li}(\% \circ)$ \\
\hline Column A & $31.1 \pm 0.08$ \\
Column C & $20.9 \pm 0.08$ \\
Column D & $31.6 \pm 0.1$ \\
Column E & $29.9 \pm 0.08$ \\
Column F & $31.7 \pm 0.1$ \\
Column G & $29.5 \pm 0.07$ \\
Column H & $30.7 \pm 0.1$ \\
Column I & $30.9 \pm 0.1$ \\
Column J & $30.9 \pm 0.09$ \\
Column K & $30.8 \pm 0.09$ \\
Column L & $32.0 \pm 0.1$ \\
Column M & $31.3 \pm 0.1$ \\
Column N & $30.7 \pm 0.1$ \\
Column O & $30.1 \pm 0.1$ \\
Column P & $30.8 \pm 0.06$ \\
Column Q & $30.6 \pm 0.07$ \\
Column R & $28.8 \pm 0.08$ \\
Column S & $31.1 \pm 0.09$ \\
Column Z & $29.3 \pm 0.08$ \\
\hline
\end{tabular}

Errors are internal analytical uncertainties reported at the $2 \sigma$ level. Column $\mathrm{C}$ was not used due to the

$\delta^{7} \mathrm{Li}$ value being significantly

different from the seawater value.
Table A2. Concentrations of lithium in reactive fluids and precipitated solids.

\begin{tabular}{lrr}
\hline Sample ID & {$[\mathrm{Li}]_{\text {sol }}\left(\mu \mathrm{g} \mathrm{L}^{-1}\right)$} & {$[\mathrm{Li}]_{\text {prec }}(\mathrm{ppm})$} \\
\hline LiDol-150-4.1 & 3695 & 25.9 \\
LiDol-150-4.2 & 3415 & 20.5 \\
LiDol-150-4.3 & 3036 & 21.8 \\
LiDol-180-4.1 & 3434 & 16.0 \\
LiDol-180-4.2 & 3238 & 15.7 \\
LiDol-220-3 & 1666 & 8.20 \\
\hline
\end{tabular}

Table A3. Mineral concentration of Nuccaleena dolostone (EC26) used in the leaching experiment.

\begin{tabular}{lr}
\hline Mineral & Concentration (wt \%) \\
\hline Quartz & 14 \\
Albite & 5.1 \\
Calcite & 1.1 \\
Dolomite & 70 \\
Ankerite & 2.1 \\
Siderite & 0.2 \\
Kaolinite & 1.0 \\
Chlorite & 0.2 \\
Muscovite & 6.2 \\
\hline
\end{tabular}

Table A4. Mineral concentrations of coral used in the leaching experiment.

\begin{tabular}{lr}
\hline Mineral & Concentration (wt \%) \\
\hline Aragonite & 97 \\
Calcite & 1.0 \\
Dolomite & 0.4 \\
Magnesite & 1.6 \\
\hline
\end{tabular}


Author contributions. HLT, AD, JF and MD designed the project; MD and IJKD conducted the precipitation experiments; HLT conducted the leaching experiments and all other analytical work; HLT and AD wrote the paper; all authors edited the paper.

Competing interests. The authors declare that they have no conflict of interest.

Acknowledgements. We would like to thank Jasmine Hunter and Helen McGregor (University of Wollongong) for providing the coral samples, Alexander Corrick (University of Adelaide) for help collecting the Nuccaleena dolomite samples and Andre Baldermann (Graz University of Technology) for performing the Li concentration analytics. The laboratory precipitation experiments and fieldwork related to this study was supported by the Base-LiNE Earth project (ITN MC Horizon 2020, grant agreement no. 643084), the Czech Science Foundation (GACR grant no. 17-18120S), the Australian Government Research Training Program and the ARC Linkage Project LP160101353.

Review statement. This paper was edited by Yves Godderis and reviewed by Yves Godderis and one anonymous referee.

\section{References}

Ahm, A.-S. C., Maloof, A. C., Macdonald, F. A., Hoffman, P. F., Bjerrum, C. J., Bold, U., Rose, C. V., Strauss, J. V., and Higgins, J. A.: An early diagenetic deglacial origin for basal Ediacaran "cap dolostones", Earth Planet. Sc. Lett., 506, 292-307, https://doi.org/10.1016/J.EPSL.2018.10.046, 2019.

Arvidson, R. S. and Mackenzie, F. T.: The dolomite problem; control of precipitation kinetics by temperature and saturation state, Am. J. Sci., 299, 257-288, 1999.

Balter, V. and Vigier, N.: Natural variations of lithium isotopes in a mammalian model, Metallomics, 6, 582-586, https://doi.org/10.1039/C3MT00295K, 2014.

Bastian, L., Vigier, N., Reynaud, S., Kerros, M.-E., Revel, M., and Bayon, G.: Lithium Isotope Composition of Marine Biogenic Carbonates and Related Reference Materials, Geostand. Geoanal. Res., 42, 403-415, https://doi.org/10.1111/ggr.12218, 2018.

Bullen, S. B. and Sibley, D. F.: Dolomite selectivity and mimic replacement, Geology, 12, 655-658, https://doi.org/10.1130/00917613(1984)12<655:DSAMR>2.0.CO;2, 1984.

Burns, S. J., Mckenzie, J. A., and Vasconcelos, C.: Dolomite formation and biogeochemical cycles in the Phanerozoic, Sedimentology, 47, 49-61, 2000.

Carignan, J., Vigier, N., and Millot, R.: Three secondary reference materials for lithium isotope measurements: Li7-N, Li6-N and LiCl-N solutions, Geostand. Geoanal. Res., 31, 7-12, 2007.

Dellinger, M., West, A. J., Paris, G., Adkins, J. F., von Strandmann, P. A. P., Ullmann, C. V., Eagle, R. A., Freitas, P., Bagard, M.-L., and Ries, J. B.: The Li isotope composition of marine biogenic carbonates: Patterns and Mechanisms, Geochim. Cosmochim. Ac., 236, 315-335, 2018.
Fairchild, I. J. and Kennedy, M. J.: Neoproterozoic glaciation in the Earth System, J. Geol. Soc., 164, 895-921, https://doi.org/10.1144/0016-76492006-191, 2007.

Flesch, G. D., Anderson, A. R., and Svec, H. J.: A secondary isotopic standard for ${ }^{6} \mathrm{Li} /{ }^{7} \mathrm{Li}$ determinations, Int. J. Mass Spectrom., 12, 265-272, 1973.

Geske, A., Zorlu, J., Richter, D., Buhl, D., Niedermayr, A., and Immenhauser, A.: Impact of diagenesis and low grade metamorphosis on isotope $\left(\delta^{26} \mathrm{Mg}, \delta^{13} \mathrm{C}, \delta^{18} \mathrm{O}\right.$ and $\left.{ }^{87} \mathrm{Sr} /{ }^{86} \mathrm{Sr}\right)$ and elemental ( $\mathrm{Ca}, \mathrm{Mg}, \mathrm{Mn}, \mathrm{Fe}$ and $\mathrm{Sr}$ ) signatures of Triassic sabkha dolomites, Chem. Geol., 332, 45-64, 2012.

Gregg, J. M., Bish, D. L., Kaczmarek, S. E., and Machel, H. G.: Mineralogy, nucleation and growth of dolomite in the laboratory and sedimentary environment: A review, Sedimentology, 62, 1749-1769, https://doi.org/10.1111/sed.12202, 2015.

Hathorne, E. C. and James, R. H.: Temporal record of lithium in seawater: A tracer for silicate weathering?, Earth Planet. Sc. Lett., 246, 393-406, 2006.

Hoefs, J.: Theoretical and Experimental Principles, in: Stable Isotope Geochemistry, Springer International Publishing, Cham, 146, https://doi.org/10.1007/978-3-319-19716-6_1, 2015.

James, R. H. and Palmer, M. R.: The lithium isotope composition of international rock standards, Chem. Geol., 166, 319-326, 2000.

Kaczmarek, S. E. and Sibley, D. F.: A Comparison of Nanometer-Scale Growth and Dissolution Features on Natural and Synthetic Dolomite Crystals: Implications for the Origin of Dolomite, J. Sediment. Res., 77, 424-432, https://doi.org/10.2110/jsr.2007.035, 2007.

Yamaji, K., Makita, Y., Watanabe, H., Sonoda, A., Kanoh, H., Hirotsu, T., and Ooi, K.: Theoretical Estimation of Lithium Isotopic Reduced Partition Function Ratio for Lithium Ions in Aqueous Solution, J. Phys. Chem. A, 105, 602-613, https://doi.org/10.1021/JP001303I, 2001.

Kunzmann, M., Halverson, G. P., Sossi, P. A., Raub, T. D., Payne, J. L., and Kirby, J.: Zn isotope evidence for immediate resumption of primary productivity after snowball Earth, Geology, 41, 27-30, https://doi.org/10.1130/g33422.1, 2013.

Land, L. S.: Failure to precipitate dolomite at 25 degrees C from dilute solution despite 1000-fold oversaturation after 32 years, Aquat. Geochem., 4, 361-368, https://doi.org/10.1023/A:1009688315854, 1998.

Lechler, M., Pogge von Strandmann, P. A. E., Jenkyns, H. C., Prosser, G., and Parente, M.: Lithium-isotope evidence for enhanced silicate weathering during OAE 1a (Early Aptian Selli event), Earth Planet. Sc. Lett., 432, 210-222, 2015.

Li, D. D., Jacobson, A. D., and McInerney, D. J.: A reactivetransport model for examining tectonic and climatic controls on chemical weathering and atmospheric $\mathrm{CO}_{2}$ consumption in granitic regolith, Chem. Geol., 365, 30-42, https://doi.org/10.1016/j.chemgeo.2013.11.028, 2014.

Liu, C., Wang, Z., Raub, T. D., Macdonald, F. A., and Evans, D. A. D.: Neoproterozoic cap-dolostone deposition in stratified glacial meltwater plume, Earth Planet. Sc. Lett., 404, 22-32, https://doi.org/10.1016/j.epsl.2014.06.039, 2014.

Liu, D., Xu, Y., Papineau, D., Yu, N., Fan, Q., Qiu, X., and Wang, H.: Experimental evidence for abiotic formation of low-temperature proto-dolomite facilitated by clay minerals, Geochim. Cosmochim. Ac., 247, 83-95, https://doi.org/10.1016/J.GCA.2018.12.036, 2019. 
Marriott, C. S., Henderson, G. M., Belshaw, N. S., and Tudhope, A. W.: Temperature dependence of $\delta^{7} \mathrm{Li}, \delta^{44} \mathrm{Ca}$ and $\mathrm{Li} / \mathrm{Ca}$ during growth of calcium carbonate, Earth Planet. Sc. Lett., 222, 615624, 2004a.

Marriott, C. S., Henderson, G. M., Crompton, R., Staubwasser, M., and Shaw, S.: Effect of mineralogy, salinity, and temperature on $\mathrm{Li} / \mathrm{Ca}$ and $\mathrm{Li}$ isotope composition of calcium carbonate, Chem. Geol., 212, 5-15, 2004b.

Misra, S. and Froelich, P. N.: Lithium isotope history of Cenozoic seawater: Changes in silicate weathering and reverse weathering, Science, 335, 818-823, https://doi.org/10.1126/science.1214697, 2012.

Pistiner, J. S. and Henderson, G. M.: Lithium-isotope fractionation during continental weathering processes, Earth Planet. Sc. Lett., 214, 327-339, https://doi.org/10.1016/s0012-821x(03)00348-0, 2003.

Pogge von Strandmann, P. A. E., Jenkyns, H. C., and Woodfine, R. G.: Lithium isotope evidence for enhanced weathering during Oceanic Anoxic Event 2, Nat. Geosci., 6, 668-672, 2013.

Pogge von Strandmann, P. A. E., Desrochers, A., Murphy, M. J., Finlay, A. J., Selby, D., and Lenton, T. M.: Global climate stabilisation by chemical weathering during the Hirnantian glaciation, Geochem. Perspect. Lett., 3, 230-237, https://doi.org/10.7185/geochemlet.1726, 2017.

Rollion-Bard, C., Vigier, N., Meibom, A., Blamart, D., Reynaud, S., Rodolfo-Metalpa, R., Martin, S., and Gattuso, J.-P.: Effect of environmental conditions and skeletal ultrastructure on the Li isotopic composition of scleractinian corals, Earth Planet. Sc. Lett., 286, 63-70, https://doi.org/10.1016/j.epsl.2009.06.015, 2009.
Rose, C. V. and Maloof, A. C.: Testing models for postglacial "cap dolostone" deposition: Nuccaleena Formation, South Australia, Earth Planet. Sc. Lett., 296, 165-180, https://doi.org/10.1016/j.eps1.2010.03.031, 2010.

Teng, F. Z., Dauphas, N., and Helz, R. T.: Iron Isotope Fractionation During Magmatic Differentiation in Kilauea Iki Lava Lake, Science, 320, 1620-1622, https://doi.org/10.1126/science.1157166, 2008.

Vasconcelos, C., McKenzie, J. A., Bernasconi, S., Grujic, D., and Tiens, A. J.: Microbial mediation as a possible mechanism for natural dolomite formation at low temperatures, Nature, 377, 220-222, https://doi.org/10.1038/377220a0, 1995.

Vigier, N. and Goddéris, Y.: A new approach for modeling Cenozoic oceanic lithium isotope paleo-variations: the key role of climate, Clim. Past, 11, 635-645, https://doi.org/10.5194/cp-11635-2015, 2015.

Wanner, C., Sonnenthal, E. L., and Liu, X.-M.: Seawater $\delta^{7} \mathrm{Li}$ : A direct proxy for global $\mathrm{CO}_{2}$ consumption by continental silicate weathering?, Chem. Geol., 381, 154-167, https://doi.org/10.1016/j.chemgeo.2014.05.005,2014.

Winkelstern, I. Z., Kaczmarek, S. E., Lohmann, K. C., and Humphrey, J. D.: Calibration of dolomite clumped isotope thermometry, Chem. Geol., 443, 32-38, https://doi.org/10.1016/j.chemgeo.2016.09.021, 2016. 